\title{
Research on Automatic Programming Methods of CNC Machining Parameters of Gear
}

\author{
X.R. Zhu \\ Jilin Teachers Institute of engineering and Technology \\ College of mechanical engineering \\ Jilin, Changchun, China
}

\begin{abstract}
-analysis tool axis and workpiece axis motion relation principle of gear hobbing and synchronous control, interface input using the key parameter, the realization of programming automatically parameters of CNC system, the parameter programming method were discussed. Application is able to simplify the processingprocedures, shortening the processing time of programming, improve processing efficiency on special occasions.
\end{abstract}

Keyword- gear; NC machining; parameter; automatic programming method

\section{INTRODUCTION}

Gear transmission is one of the main ways of the machine movement and power transmission, it is widely used in all kinds of mechanical equipment and instruments. But in gear machining, cutting method as the domestic and foreign application of hobbing most widely, is decided by its steady processing, good anti vibration characteristics. The number of moving coordinate axis hobbing machine, the linkage relation is very complex, the machining process and the gear is to keep dividingin the workpiece and tool case synchronously generating motion and complete, is a complex process. The NC system of gear hobbingmachine, different motion axis of machine tool of numerical control, so that between the corresponding coordinates with linkage relationship.[2][6]

In actual processing, due to the movement of the complex relationship,hobbing is divided into a plurality of step to finish machining process, so the programming method of cutter locations often procedure based onthe large amount of. But because of the different characteristics ofsimple processing gear, gear between the process is similar, can realize the parametric programming. That is, with a few parameters of gearmachining feature representation, processing program for gear hobbingrequirements so as to automatically build.[1][6][10]

\section{THE ANALYSIS OF PARAMETERIZED PROGRAMMING GEAR NC MACHINING}

The principle of gear hobbing is cutting by generating method of. Rotary motion hob with cutting groove and the spiral angle of the hypotheticalform linear movement, the workpiece according to hob helix angle, the direction of rotation is in accordance with the provisions of the methodfor rotary movement. Therefore, gear hobbing machine hob and table in addition to rotating exhibition into motion, the general must also havethe axial feed motion, radial feed motion and tangential feed movement.Among them, the rolling key tooth machine control is thesynchronization between the workpiece and the spindle shaft: hobturned a turn, the workpiece is just turned a tooth. The typical five axeshobbing machine. The control shaft is respectively: $\mathrm{X}$ axial - radial feeding movement; Y axis - tangential feed movement; the $\mathrm{Z}$ shaft axial feed motion; $B$ shaft hob rotary motion; the $C$ axis rotary table a motion-. Y axis control gear circumferential surface of the axis of motion, is actually moving direction by generating motion is imaginary rack; the $\mathrm{Z}$ axis is the axis of motion control of tooth thickness; $\mathrm{B}$ axis is the hobrotating axis of motion control; $\mathrm{C}$ axis is the control shaft rotary motionworktable, is mainly used to control the angle of installation angle andbevel gear machining.[5]

Gear structure is complex, but its shape is generated by certain rules.As long as you know the general cylindrical gear modulus $\mathrm{m}$, pressure angle, addendum coefficient ha*, radial clearance coefficient $\mathrm{c}^{*}$ and tooth number $\mathrm{Z}$, other parameters can be determined from table 1.[8]

TABLE I. GEAR PARAMETER CONVERSION FORMULA.

\begin{tabular}{|c|c|c|}
\hline The name & Symbol & Formula \\
\hline $\begin{array}{c}\text { pitch diameter;standard pitch } \\
\text { diameter }\end{array}$ & $\mathrm{d}$ & $\mathrm{d}=\mathrm{mz}$ \\
\hline $\begin{array}{c}\text { base circle diameter } \\
\text { (BCD);base diameter }\end{array}$ & $\mathrm{d}_{b}$ & $\mathrm{~d}_{b}=\mathrm{d}$ cosa \\
\hline tip diameter & $\mathrm{d}_{a}$ & $\mathrm{~d}_{a}=\left(\mathrm{Z}+2 \mathrm{ha}^{*}\right) \mathrm{m}$ \\
\hline root diameter & $\mathrm{d}_{f}$ & $\mathrm{~d}_{f}=\left(\mathrm{Z}-2 \mathrm{ha}^{*}-\mathrm{c}^{*}\right) \mathrm{m}$ \\
\hline $\begin{array}{c}\text { Tooth addendum;tooth head; } \\
\text { addendum }\end{array}$ & $\mathrm{h}_{a}$ & $\mathrm{~h}_{a}=\mathrm{ha}^{*} \mathrm{~m}$ \\
\hline dedendum & $\mathrm{h}_{f}$ & $\mathrm{~h}_{f}=\left(\mathrm{ha}^{*}+\mathrm{c}^{*}\right) \mathrm{m}$ \\
\hline whole depth & $\mathrm{h}$ & $\mathrm{h}_{=} \mathrm{h}_{a}+\mathrm{h}_{f}=\left(2 \mathrm{ha}^{*+} \mathrm{c}^{*}\right) \mathrm{m}$ \\
\hline Tooth pitch & $\mathrm{p}$ & $\mathrm{p}=\mathrm{m} \pi$ \\
\hline space width & $\mathrm{e}$ & $\mathrm{e}=\mathrm{m} \pi / 2$ \\
\hline Tooth thickness & $\mathrm{s}$ & $\mathrm{s}=\mathrm{m} \pi / 2$ \\
\hline
\end{tabular}

Because the gear processing characteristics, CNC system for hobbing machine programming and common millingCNC system is completely different. Gear machining is not convenient to directly describe the processing path, if the input gear hob parameters, tool parameters, special gearto input data of gear, and the gear machining processaccording to the input data, and then by the CNC systemis calculated and converted 
to a coordinate axismovement of the program, which will direct than on gear processing knife site programming convenient and simple.This is the parameter automatic programming.[3]

The specific parameters and the meaning of gear parametric automatic programming required as shown in table 2:[9]

TABLE II. GEAR PARAMETRIC PROGRAMMING REQUIREDPARAMETERS.

\begin{tabular}{|l|l|l|l|}
\hline $\begin{array}{l}\text { tool } \\
\text { parameter }\end{array}$ & $\begin{array}{l}\text { gear } \\
\text { parameters }\end{array}$ & $\begin{array}{l}\text { The tooth } \\
\text { profile } \\
\text { parameters }\end{array}$ & Process data \\
\hline Modulus & lead angle & $\begin{array}{l}\text { Bone shaped } \\
\text { inner diameter }\end{array}$ & $\begin{array}{l}\text { Finish } \\
\text { machining } \\
\text { allowance }\end{array}$ \\
\hline pressure angle & tooth width & $\begin{array}{l}\text { Addendum } \\
\text { angle }\end{array}$ & Cutting times \\
\hline $\begin{array}{l}\text { Cutter } \\
\text { diameter }\end{array}$ & $\begin{array}{l}\text { Outside } \\
\text { diameter of } \\
\text { gear blank }\end{array}$ & Root angle & $\begin{array}{l}\text { Rough } \\
\text { machining } \\
\text { speed }\end{array}$ \\
\hline $\begin{array}{l}\text { The number of } \\
\text { cutter head }\end{array}$ & $\begin{array}{l}\text { number } \\
\text { teeth }\end{array}$ & whole depth & $\begin{array}{l}\text { Machining } \\
\text { speed }\end{array}$ \\
\hline$\ldots . . .$. & $\ldots . .$. & $\begin{array}{l}\text { Radial feed } \\
\text { speed }\end{array}$ \\
\hline & & $\begin{array}{l}\text { Installation } \\
\text { Base Surface }\end{array}$ \\
\hline
\end{tabular}

Thus, as long as the determination of parameters of basic, other related dimensions can be calculatedaccording to the formula of processing, so the parametric processing is feasible for gear. As long as the parameters of the interface input processing required parameters, can be calculated by the numerical control system and the automatic generation of machining program. Therefore,the parameters of NC programming is of universal significance to analyze and conclude the promotion, as long as the product machining and programming ideas, toestablish its model, so as to realize the parametric programming. It is suitable for special parts processing.[4][7]

\section{ANALYSIS OF CONTROL CNC GEAR HOBBING MOVEMENT}

Hobbing is by a pair of gears of the same modulus and pressure angle are engaged with each other, according to the principle of conjugate tooth profile of gear cuttingenveloping each other to. Hobbing hob and gear blank,pure rolling in the day round place, the envelope can betooth profile hob is involute tooth profile of gear machining. Can also be hob rotary motion is equivalent tothe rack moves through the rack and the gear blank,meshing motion realization of gear hobbing. By a coordinate transformation that in coordinate system $\mathrm{O}$ $-\mathrm{xY} \mathrm{Z}$ hob, if moving a distance $\mathrm{L}$, in the $\mathrm{O}-\mathrm{x} \mathrm{Y} \mathrm{Z}$ gear blankgear coordinate rotation angle. Because of the hob andgear blank pure rolling do on the pitch circle, then there is a relation between the $=\mathrm{L} / \mathrm{r}$. When different $\mathrm{L}$ values, can rotate with different angles. Thus, when used as a hobrack to move forward, leaving a series of specific location in the path, thus formed the tooth profile lines envelopinggraph is the gear blank. As shown in figure 1.

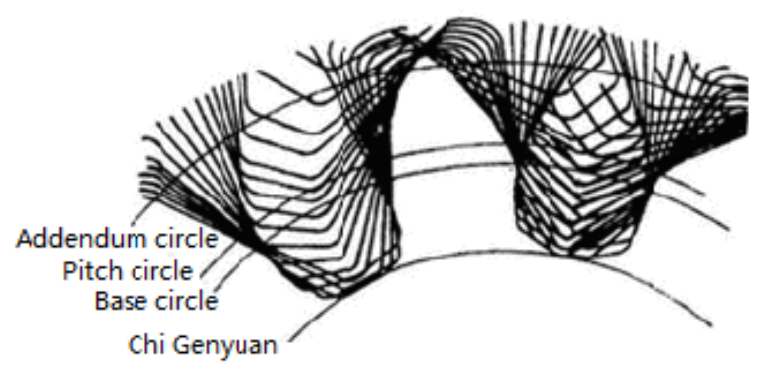

FIGURE I. HOBBING TOOTH PROFILE ENVELOPE.

\section{THE RELATIONSHIP BETWEEN THE ROLLING MOTION GEAR MACHINING IS DERIVED}

Because the traditional hobbing machine for machining error response time lag, there are large, the currentmodel hobbing system, using double driven synchronouscontrol method to realize synchronous motion control ofaxis, it adopts phase locked servo high precisionsynchronous precision control, high precision, fast response speed. How to put the relationship betweentooth movement into movement relationship of equivalentrack gear machining, is the key to the movement of NC machining. Hob speed ( $\mathrm{r} / \mathrm{min})$ to $\mathrm{n}$ rotation, equivalent tothe rack at a speed of $\mathrm{V}(\mathrm{mm} / \mathrm{min})$ mobile. A hob rotates one circle time used for $\mathrm{T}$, there are:

$$
\mathrm{n}_{\text {knife }} \mathrm{t}=2 \pi
$$

At this time, the equivalent of the rack to move forward apitch P:

$$
\mathrm{P}=v t
$$

According to the pitch of the size definition:

$$
\mathrm{P}=\mathrm{m} \pi
$$

From the above relations, can launch hob speed (r/min)and $\mathrm{V}$ (mm/min rack rate) relationship:

$$
\mathrm{V}=m / 2 n_{\text {knife }}
$$

By (1) to (4) may be introduced in hobbing movement, the relationship between hob shift knife every forward stepand gear blank rotation angle as required:

$$
\theta_{\text {work }}=\frac{\mathrm{n}_{\text {knife }}}{\mathrm{z}_{\text {work }}} \cdot \frac{180}{\pi}=\frac{2 \pi}{\mathrm{v}} \cdot \mathrm{p} \cdot \frac{1}{\mathrm{z}_{\text {work }}} \cdot \frac{180}{\pi}=\frac{360 \cdot \mathrm{m} \cdot \pi}{\operatorname{Step}_{\text {knife }} \cdot \mathrm{z}_{\text {work }}}
$$

In the roll cutting, radial feed is ensured by means of two times the amount of feed. The first rough cut out most ofthe tooth height, can according to the gear size to the processing of the determined. Second finishing is based on the first processing, according to the measure for the first time after rough machining of gear common normal length $1 \mathrm{~W}$, to determine the second times the amount of feed h:

$$
\Delta \mathrm{h}=\frac{W_{1}-W}{2 \sin \alpha}
$$

Compute the motion relationship between the radial and axial direction of the hob and gear blanks, position change can be programmed to calculate each moment.The motion state is 
continuous, it can put the gear hobbing movement continuous discrete representation.[10]

\section{CONCLUSION}

Gear tooth surface NC processing must be carried out bycomputer aided, according to the tooth surface of thedigital data, the automatic generation of NC codecorresponding to the tool parameters and installation parameters. We analyzed the roll key movement in gear processing, generating motion and its decomposition into the relationship between the two synchronous shaft. So as long as the given conjugate generating motioncorresponding to get another generating motion of thegenerating NC code.

To realize the parameterized hobbing programming,depends on the compiler can complete the programming function, namely according to the workpiece, the tool datadata, process data and related parameters of cuttingmachine to automatically generate $G$ code function.Automatic programming to the operator for processingthrough the processing parameters of gear control panel input, NC machining program of gear machining CNCsystem can identify and automatically, to simplify the process of the operator's operation.

\section{REFERENCE}

[1] Feng Zhigang. Techniques and examples of macro program of CNC Machinery Industry Press.2007. method.

[2] http://www.hhservice.com.cn/bj/ CNC technology, 2005

[3] Wang Huaqiao, Zhang Ying, Wang Deyue..2006 NC milling programming function of CAD/CAM in contrast withthe informatization of manufacturing industry of typical CAM platform, No.4:78 82

[4] Li Mingyao. Die CAD/CAM. Machinery Industry Press.2004

[5] Zhang Ru. Based on the software control of economictype NC milling machine Windows system research[Master thesis. Shaanxi: Northwestern Polytechnical University,.2004

[6] Wu Zuyu, Qin Pengfei. Numerical control machine. Shanghai science and Technology Press, 2000

[7] Technologies Enabling Agile Manufacturing (Team)Intelligent Closed Loop Processing (LCLP) API WorkingGroup Open Architecture Specification Part I GeneralInformation.Jan.1996.

[8] FANUC Series 21i-MB; FANUC Series 21Oi-MB

[9] Huazhong HNC-21T CNC lathe programming manual

[10] Zhao Jiao, and Realization of compiler [Master thesis. Shanghai research special programming NC: Shanghai Jiao Tong University.2008.01 